\title{
Analisis dan Penanganan Perilaku Kecenderungan Cinderella Complex
}

\author{
Muhammad Afiq Fauzan \\ Bimbingan \& Kanseling \\ Universitas Negeri Makassar \\ Email: afiqfauzan71回gmail.com
}

\section{ABSTRACT}

The problem in this research is that there is 1 student who experiences the Cinderella Complex at the Faculty of Education, UNM. The main study of this research is to determine: (1) General description of the behavior of thetendency Cinderella Complex in a student at the Faculty of Education, UNM. (2) The factors that cause thetendency behavior Cinderella Complex in a student at the Faculty of Education, UNM. (3) Efforts that can be made by female students who experiencetendencies Cinderella Complex in a student at the Faculty of Education, UNM. The approach to this research is qualitative with the type of case study research. Data were collected through interviews, observation and documentation. Data analysis used descriptive analysis with triangulation techniques. The results obtained are: (1) a description of the tendency ofbehavior Cinderella Complex in a student at the Faculty of Education, UNM, which refers to the student who expects more guidance or help from men or other people. (2) the factors that cause the tendency ofbehavior Cinderella Complex in a student at the Faculty of Education, UNM, namely the parenting style that is applied in her family, and also self-concept. (3) Efforts that can be made by a student who experiences a tendency towardsbehavior Cinderella Complex in a student at the Faculty of Education UNM, namely counseling using Cognitive Restructuring techniques can reduce the tendency ofbehavior Cinderella Complex in female students at the Faculty of Education UNM.

Keywards: Case Study, Tendency Cinderella Complex, Cognitif Restructuring.

\section{ABSTRAK}

Masalah dalam penelitian ini yaitu terdapat 1 orang siswi yang mengalami Cinderella Complex di Fakultas Ilmu Pendidikan UNM. Kajian utama penelitian ini adalah untuk mengetahui : (1) Gambaran umum perilaku kecenderungan Cinderella Complex pada seorang mahasiswi di Fakultas Ilmu Pendidikan UNM. (2) Faktor-faktor yang menyebabkan perilaku kecenderungan Cinderella Complex pada seorang mahasiswi di Fakultas Ilmu Pendidikan UNM. (3) Upaya yang dapat dilakukan mahasiswi yang mengalami perilaku kecenderungan Cinderella Complex pada seorang mahasiswi di Fakultas Ilmu Pendidikan UNM. Pendekatan pada penelitian ini adalah kualitatif dengan jenis penelitian studi kasus. Pengambilan data dilakukan melalui wawancara, observasi, dan dokumentasi. Analisis data menggunakan analisis deskriptif dengan teknik triangulasi. Hasil penelitian yang diperoleh yaitu: (1) gambaran kecenderungan perilaku Cinderella Complex pada seorang mahasiswi di Fakultas Ilmu Pendidikan UNM merujuk pada mahasiswi tersebut lebih banyak mengharapkan pengarahan atau pertolongan dari laki-laki atau orang lain. (2) faktor-faktor yang menyebabkan kecenderungan perilaku Cinderella Complex pada 
seorang mahasiswi di Fakultas Ilmu Pendidikan UNM yakni pola asuh yang diterapkan dalam keluarganya, dan juga konsep diri. (3) Upaya yang dapat dilakukan mahasiswi yang mengalami kecenderungan perilaku Cinderella Complex pada seorang mahasiswi di Fakultas Ilmu Pendidikan UNM yakni dilakukan konseling dengan menggunakan teknik Restrukturisasi Kognitif dapat mengurangi kecenderungan perilaku Cinderella Complex pada mahasiswi di Fakultas Ilmu Pendidikan UNM.

Kata Kunci: Studi Kasus, Kecenderungan Cinderella Complex, Restrukturisasi Kognitif

\section{PENDAHULUAN}

Perkembangan kepribadian manusia dengan berbagai macam latar belakangnya yang secara langsung dan tidak langsung saling berpengaruh dan mempengaruhi satu dengan yang lainnya. Salah satunya adalah perkembangan IPTEK yang mempengaruhi setiap individu dalam memulai hidupnya dengan sifat ketergantungan, kemudian individu akan menuju kepada kemandirian.

Danuri (1990: 54) menjelaskan bahwa kemandirian adalah suatu sikap yang memungkinkan seseorang untuk bertindak bebas untuk melakukan sesuatu atas dorongan diri sendiri dan untuk kebutuhan sendiri, mengejar prestasi, berkeinginan untuk mengerjakan sesuatu tanpa bantuan orang lain, mampu mempengaruhi lingkungannya, mempunyai rasa kepercayaan terhadap dirinya sendiri, menghargai keadaan dirinya dan mempunyai kepuasan atas usaha yang telah ia lakukan. Tanpa kemandirian orang tidak mungkin menguasai dan mempengaruhi lingkungannya, tetapi justru akan banyak menerima pengaruh dari lingkungan dan dikuasai oleh lingkungannya.

Tetapi kemandirian pada masa lalu belum disadari oleh wanita, menurut Symonds (Dowling, 1992: 27-28) wanita akan cenderung merendahkan diri pada orang lain, tidak mandiri dan secara tidak sadar menggunakan sebagian besar energinya untuk mendapatkan cinta, pertolangan dan perlindungan terhadap apa yang kelihatannya sulit, atau menantang didunia ini, walaupun sebenarnya mereka adalah wanita yang berhasil. Seperti keadaan sekarang, rata-rata hampir setiap orang tua menginginkan anak perempuannya tumbuh berkembang dengan penuh kasih sayang, sehingga mereka melayani anak perempuannya layaknya searang tuan putri kerajaan. Akan tetapi siapa sangka, perlakuan yang di dapatkannya tersebut dapat mempengaruhi aspek psiknlogis mereka.

Wulansari (2010), berdasarkan hasil penelitian yang dilakukan mengatakan bahwa terdapat sedikit sumbangan knnsep diri terhadap kecenderungan Cinderella Complex, hal ini karena terdapat faktor lainnya yang ikut mempengaruhi kecenderungan Cinderella Complex. Faktor lain tersebut adalah faktor eksternal meliputi sasial budaya, peran penting lingkungan, media massa dan faktor internal yaitu harga diri.

Kecenderungan yang terjadi secara nyata dikalangan kaum perempuan terutama pada remaja tentu saja tidak terlepas dari konsep diri yang juga ikut berperan penting dalam proses perkembangan kepribadian dan harga diri. Jadi keduanya saling terikat dan saling berhubungan satu terhadap yang lainnya. Keyakinan yang tumbuh di dalam konsep diri perempuan tentang stereatipe yang di internalisasikan dan di sasialisasikan lingkungan serta harga diri yang rendah mengakibatkan perempuan mengalami kecenderungan Cinderella Camplex.

Kecenderungan Cinderella Complex ialah kecenderungan perempuan untuk ketergantungan secara psikis yaitu adanya keinginan yang kuat untuk dirawat dan dilindungi arang lain terutama laki-laki serta keyakinan bahwa sesuatu dari luar dirinya yang akan menolangnya. Kecenderungan Cinderella Complex dapat terjadi karena adanya rasa takut yang tanpa disadari dalam diri perempuan, "Apakah dirinya bisa mandiri?" dan terdapat pandangan sasial bahwa perempuan adalah sasok yang manja dan memiliki ketergantungan yang berlebihan terhadap orang lain khususnya kepada laki-laki. 
Cinderella Complex terbentuk atau juga dapat dipengaruhi dari perbedaan perlakuan yang diterima oleh anak perempuan dan anak laki-laki ketika kecil. Sejak kecil anak perempuan mendapatkan dispensasi secara tidak langsung dalam hal kemandirian. Pria dididik untuk menjadi mandiri sejak hari mereka dilahirkan dengan cara yang sama sistematisnya, wanita diajarakan untuk tidak dikhawatirkan kepada permasalahan yang besar, sedangkan pria dituntut untuk bisa melakukan berbagai macam hal. Namun hal tersebut dipengaruhi oleh bagaimana budaya mempengaruhi stereatipe dalam membedakan antara laki-laki dan perempuan (Vargheze, 2015).

Adapun aspek-aspek yang membentuk Cinderella Complex yaitu: Pertama, keinginan untuk dirawat yaitu keinginan untuk mendapat perhatian yang lebih dari orang lain (khususnya laki-laki) dan merasa dirinya penting. Misalnya, remaja perempuan merasa bahwa dirinya sudah cukup dewasa untuk berpacaran sehingga orang tua harus memberikan ijin. Kedua, keinginan untuk dilindungi dan disayangi yaitu keinginan untuk mendapat kasih sayang yang memuaskan dari orang tua dan kekasihnya. Misalnya, apabila terjadi permasalahan dengan pacarnya, orang tua harus merangkul dan menolangnya dengan penuh kasih dan bukan membiarkan permasalahan terus berlarut-larut. Ketiga, keyakinan yang kuat akan adanya sesuatu dari luar yang akan menolongnya. Maksudnya, remaja perempuan yakin bahwa pacarnya yang menjadi ketergantungannya akan menolongnya dari semua permasalahan hidup (Dawling, I992).

Istilah cinderella complex diambil dari salah satu tokoh cerita dongeng yaitu Cinderella yang sebagaimana menantikan hadirnya sasok Pangeran yang di idam-idamkan menyelamatkan dirinya dari ketidaknyamanan dan kesengsaraan. Istilah complex menurut Jung merupakan sekelompok ide (perasaaan, pikiran, persepsi, dan ingatan) yang terorganisir menjadi satu (Prasetyani, 2013).

Sesearang atau individu dapat dikatakan complex ketika individu tersebut dipengaruhi oleh sesuatu yang dapat membuatnya jenuh dan menyerah, sehingga sesuatu tersebut hampir mempengaruhi semua tingkah lakunya. Istilah complex kemudian memiliki konotasi patologis, sebab cukup banyak dipakai oleh kalangan psiknanalisis dan psikiater, untuk memberikan ciri karakteristik terhadap sekelompok ide atau impuls yang berkonflik hebat dengan berbagai aspek kepribadian lainny. Akan tetapi konsep itu tidak mengandung implikasi abnormalitas, dan bisa digunakan untuk mencirikan asasiasi hasrat, impuls dan sentimen yang berlangsung pada pribadi yang normal. Maka dari itu, selanjutnya complex tidak diartikan sebagai sebuah abnormalitas melainkan complex dialami oleh pribadi yang normal (Prasetyani, 2013).

Kecenderungan cinderella complex menurut Downing (Muthmainnah, 2012) adalah ketergantungan secara psikologis pada perempuan dan terdapat keinginan yang kuat untuk dirawat, dilindungi urang lain (laki-laki) dan keyakinan bahwa sesuatu diluar dirinyalah yang akan menolongnya. Sindram ketakutan kemandirian tersebut merupakan kekuatan utama guna melumpuhkan perempuan, sehingga tidak berani memanfaatkan sepenuhnya kekuatan atak dan kreatifitasnya.

Dowling (Prasetyani, 2013) telah mewawancarai banyak perempuan, dan dari hasil wawancara yang di dapatkannya tersebut menyatakan bahwa banyak perempuan yang tidak menyadari masalah ketergantungan ini. Mereka mengatakan bahwa yang mereka inginkan adalah kemerdekaan, namun secara emosional, mereka memperlihatkan dengan tanda-tanda penderitaan karena mengalami suatu konflik batin yang begitu mendalam. Dengan kata lain, bisa dikatakan perempuan senantiasa mendambakan kemandirian, namun secara sisi psikis perempuan juga selalu mengharapkan perhatian dan perlindungan dari orang lain (laki-laki).

Perempuan juga berkemungkinan untuk menyerah setiap kali mengalami masalah yang cukup berat dan ingin mendapatkan suatu perlindungan dari searang laki-laki. Hal inilah yang menjadi pemicu berkurangnya keinginan perempuan dan kekuatan perempuan untuk menjadi seorang yang mandiri, serta tidak berani untuk menghadapi masalahnya sendiri. 
Berdasarkan dari beberapa pengertian Cinderella Complex yang telah dijelaskan oleh beberapa tokoh ahli ters ebut, maka dapat disimpulkan bahwa perilaku kecenderungan Cinderella Camplex ditandai dengan tingginya intensitas meminta bantuan kepada orang lain utamanya laki-laki, seringnya menghindari tantangan atau kompetisi serta takut kehilangan sisi feminimitas yang dimiliki deh perempuan tersebut. Perempuan selalu merasa ingin menyerah tiap kali mengalami masalah yang berat sehingga iya sangat bergantung kepada orang lain atau laki-laki untuk dijadikan sebagai tameng melindungi dirinya.

Berdasarkan observasi yang pernah dilakukan sebelumnya oleh peneliti di Fakultas IImu Pendidikan UNM, terindikasi ada searang mahasiswi yang berinisial $\mathrm{NDH}$ memiliki kecenderungan cinderella complex. Hal ini ditandai dengan tingginya ketergantungan pada orang lain utamanya pada laki-laki seperti ketika menghadapi suatu masalah yang menurutnya dapat membuat dirinya pusing/ribet sehingga ia bergantung kepada orang lain yang mengakibatkan timbul persepsi bahwa akan ada orang lain yang menolongnya setiap menghadapi suatu masalah, selalu meminta arahan kepada orang lain seperti ketika dirinya ingin mengerjakan sesuatu ataupun ketika ingin mengambil suatu keputusan harus ada persetujuan / pengesahan secara sasial, menghindari tantangan-tantangan ataupun kompetisi yang dapat mempersulit diri seperti saat diberikan tugas tambahan secara individu yang sifatnya berbatas waktu yang singkat, merasa takut kehilangan feminitas dalam melakukan suatu pekerjaan. Adapun cirinya yaitu cuek, manja, suka melawan, pemalas dan suka marah. Untuk dampak yang ditampilkan secara langsung oleh NDH ketika mengalami suatu kecenderungan Cinderella Complex yaitu kecewa, putus asa, suasana hati berubah-ubah.

Mahasiswi yang memiliki kecenderungan Cinderella Complex ini memiliki pemikiran-pemikiran irrasional yang muncul karena kebiasaan perilaku yang diterimanya sejak kecil dimana anak perempuan dididik untuk lebih bersifat mengasuh, tidak didarang untuk melath fisiknya melainkan lebih untuk menumbuhkan feminitasnya yang selanjutnya membentuk sekelompok ide yang terorganisir membentuk kecenderungan Cinderella Complex, berupa ketergantungan pada orang lain.

Pendekatan belajar pada kecenderungan Cinderella Complex yang menyebabkan adanya ketakutan akan ketiadaan kemandirian pada diri perempuan dan rasa ingin ditolong oleh pihak luar (laki-laki) melalui proses belajar yang diterapkan dalam pola pengasuhan dan lingkungan sekitar anak perempuan yang selalu menempatkan anak perempuan pada pasisi yang selalu dilindungi.

Anak perempuan belajar untuk meniru atau mengimitasi perilaku-perilaku yang dilakukan oleh ibu mereka. hal tersebut berjalan sejalan dengan teori psiknanalitik yang menyatakan bahwasanya pada usia 4-5 tahun seorang anak mengalami proses identifikasi dengan orang tua mereka yang berjenis kelamin sama (Hurlock, 20II). Anak menyerap karakteristik kepribadian maskulin atau feminim dari orang tua bersangkutan dan menggunakan banyak nilai serta karakteristik arang tua tersebut.

Dalam penelitiannya Sa'diyah (Nurmaila dalam Erwin, 2017) mengungkapkan teori cinderella camplex sebagai berikut:

1) Teari Dowling

Kecenderungan secara termiologi sebagian besar digunakan untuk mendefinisikan kondisi keterbukaan yang jelas dalam pengobatan medis. Namin demikian, dalam perkembangan zaman terminologi tersebut sudah banyak digunakan di luar konteks masalah kesehatan melainkan juga merujuk pada kombinasi fenomena yang terlihat membentuk asasiasi. Kecenderungan Cinderella Complex tercermin dari beberapa ungkapan Dowling (Nurmaila, 2016) bahwa secara psikologis perempuan yang berusaha menghindari kemandirian menimbulkan "keinginan untuk diselamatkan" adalah menjadi sebuah isu yang penting dihadapi oleh kebanyakan perempuan saat ini. Sa'diyah (Nurmaila dalam Erwin, 2017) juga menambahkan bahwa: 
Perempuan dibesarkan untuk tergantung pada laki-laki dan merasa lemah tanpa kehadiran lakilaki. Masyarakat diajarkan untuk percaya bahwa perempuan tidak bisa mandiri diatas kakinya sendiri, bahwa perempuan terlalu rapuh, terlalu delikatif, membutuhkan perlindungan. Sehingga sekarang ini, saat intelektual perempuan menyuruh untuk mandiri, isu-isu emosional yang tidak terpenuhi bertindak sebaliknya. Pada saat yang sama ingin menjadi manusia yang bebas sekaligus juga dilindungi.

Perempuan menghindari kemandirian dikarenakan adanya keinginan untuk diselamatkan. Pemahaman yang telah berkembang di mas yarakat bahwa perempuan tidak mampu berdiri sendiri dan lemah tanpa sasok laki-laki. Perempuan dibesarkan untuk bergantung kepada arang lain. Dimulai sejak di dalam lingkungan keluarganya bergantung kepada arang tuanya dan orang dewasa lainnya. Kemudian setelah beranjak dewasa perempuan diajarkan untuk mulai bergantung pada sasok laki-laki. Namun sekarang ini, perempuan dituntut untuk mandiri dengan memanfaatkan intelektualnya, walaupun emosionalnya bertindak sebaliknya. Pada disaat yang sama perempuan juga ingin menjadi individu yang bebas sekaligus di lindungi.

Dari penjelasan yang telah ada, maka dapat disimpulkan bahwa perilaku kecenderungan Cinderella Complex disebabkan oleh sebuah proses belajar dari lingkungan yang secara psikologis perempuan berusaha menghindari kemandirian yang menimbulkan "keinginan untuk diselamatkan" sehingga timbul persepsi dimasyarakat bahwa perempuan tidak mampu untuk berdiri sendiri dan lemah tak berdaya tanpa adanya sasak laki-laki.

\section{a. Penyebab Cinderella Complex}

\section{1) Pola Asuh}

Berbicara mengenai faktor-faktor penyebab cinderella complex yang terjadi pada perempuan, Dowling (1992:29) memaparkan, bahwa "perempuan dari dulu di didik berbeda dari pria, anak perempuan tidak diajarkan untuk bersikap asertif, dan lebih bertanggungg jawab. Pola asuh orangtua merupakan segala sesuatu yang dilakukan orang tua untuk membentuk perilaku anak-anak mereka meliputi semua peringatan dan aturan, pengajaran dan perencanaan, contoh dan kasih sayang serta pujian dan hukuman.

Anggraini \& Astuti (2003: 50), pola asuh berpengaruh pada terjadinya kecenderungan Cinder ella complex pada perempuan. Karena Keluarga merupakan kelompok sasial yang pertama dimana anak dapat berinteraksi.

Ki Hajar Dewantara (Moh. Shochib, 1998:(I) menyatakan bahwa keluarga merupakan pusat pendidikan yang pertama dan terpenting, karena sejak timbulnya peradaban manusia sampai sekarang keluarga selalu mempengaruhi pertumbuhan budi pekerti tiap-tiap manusia. Lingkungan keluarga merupakan tempat di mana searang anak berinteraksi untuk pertama kalinya. Pada lingkungan keluarga pula seorang anak menerima ajaran-ajaran dan didikan dari orangtuanya, sehingga hal tersebut secara tidak langsung akan mempengaruhi perilaku sasialnya.

Menurut Hurlock (1992) secara umum ada tiga macam pola asuh orangtua terhadap anak yaitu, tipe pola asuh pertama demokratis, tipe pola asuh kedua adalah permisif, tipe pola asuh ketiga adalah otoriter. Ketiga pola asuh arangtua tersebut memiliki karakteristik yang berbeda-beda. Gaya pengasuhan yang berbeda-beda terhadap anak akan menghasilkan sikap dan perilaku berbeda-beda pula Sebagaimana yang diungkapkan Abu Ahmadi (I9SI) bahwa, Imam Thasali menyatakan, anak itu sifatnya menerima semua yang dilakukan, yang dilukiskan dan condang kepada semua yang tertuju kepadanya. Jika anak itu dibiasakan dan diajari berbuat baik maka anak itu akan hidup berbahagia di dunia dan akhirat. Dari kedua orang tua serta semua guru-gurunya dan pendidik-pendidiknya akan mendapat kebahagiaan pula dari kebahagiaan itu. Tetapi jika dibiasakan berbuat jahat dan dibiarkan begitu saja, maka anak itu akan celaka dan binasa.

Menurut Saha (2016) Bagi wanita yang menderita Cinderella yang tipe kompleks, ketergantungan dan rendah diri tampaknya menjadi akar penyebab masalah. Kebanyakan psikolog percaya bahwa dalam banyak kasus masalah 
ketergantungan mungkin akibat dari orangtua sangat over-protektif. Bahkan, orang tua ini mungkin telah meningkat perilaku pelindung normal menjadi pengendali kasar, dalam beberapa kasus bahkan menghukum anak untuk menampilkan tanda-tanda kemerdekaan. Hal ini juga dianggap kemungkinan bahwa wanita yang menderita kompleks ini dipermalukan secara sasial selama tahun-tahun formatif mereka, yang sering menjadi penyebab harga diri yang rendah.

\section{2) Kematangan Diri}

Menurut George (2006), kematangan merupakan proses terus-menerus sebuah sistem organisme dalam mencapai kedewasaan kelakuan, yang memantapkan reaksi-reaksi organisme terhadap alam sekitar sedemikian rupa, sehingga menjadi mampu mempertahankan keutuhan arganisme sesuai dengan keadaan dewasa, yang dihasilkan dari proses pemasakan. Faktor-faktor yang mempengaruhi kematangan kepribadian menurut Schneider (dalam Iswatiningrum, 2013) sebagai berikut

a. Kondisi fisik, meliputi hereditas, keadaan fisik,kesehatan, penyakit dan lain-lain.

b. Perkembangan dan kematangan, khususnya kematangan intelektual, susial, moral, dan emasional.

c. Faktor-faktor psikologis, meliputi pengalaman, frustasi, maupunkonflik.

d. Kondisi lingkungan.

e. Faktor budaya, meliputi adat.

Keyakinan yang tumbuh di dalam kematangan kepribadian perempuan dinilai orang lain berdasarkan persepsi yang dimilikinya dan dipengaruhi oleh lingkungan serta pribadi yang tidak matang mengakibatkan perempuan mengalami kecenderungan cinderella complex. Kecenderungan cinderella complex akan berpengaruh terhadap cara perempuan berinteraksi dengan lingkungannya dan ketika menghadapi kesempatan untuk mengembangkan diri serta dalam menghadapi permasalahan.

\section{3) Konsep Diri}

Calhoun \& Acacella (dalam Wulandari, 20IC) menyatakan bahwa individu yang memiliki kansep diri yang negatif akan memiliki penilaian negatif terhadap dirinya sehingga merasa bahwa dirinya tidak cukup berharga dibandingkan arang lain. Individu yang memiliki konsep diri yang positif akan memiliki penilaian yang positif terhadap dirinya sehingga dapat menerima dirinya sendiri secara apa adanya.

Effendi (dalam Dewi dkk, 2004) menyatakan bahwa konsep diri antara laki-laki dan perempuan berbeda karena perlakuan orang lain yang berbeda, karena perlakuan masyarakat atau lingkungan terhadap laki-laki dan perempuan. Keyakinan yang tumbuh di dalam konsep diri perempuan tentang stereatipe yang diinternalisasikan dan disasialisasikan lingkungan serta harga diri yang rendah mengakibatkan perempuan mengalami kecenderungan Cinderella Complex. Kecenderungan Cinderella Camplex akan berpengaruh terhadap cara perempuan berinteraksi dengan lingkungannya dan ketika menghadapi kesempatan untuk mengembangkan diri serta dalam menghadapi permasalahan.

Konsep diri yang dimiliki perempuan terdapat sebuah stereatip akan feminitas yang diberikan oleh masyarakat (Wulansari, 20I0). Konsep diri tidak pernah lepas dari proses tumbuh kembangnya kepribadian sesearang (Eriksan dalam Qudsiyah, 2019). Menurut penelitian sebelumnya yang dilakukan oleh Wulansari (2010) menunjukkan bahwa terdapat hubungan yang negatif antara knnsep diri dengan kecenderungan Cinderella Complex pada mahasiswi Fakultas Psikologi Universitas Diponegoro. Semakin positif konsep diri maka semakin rendah tingkat kecenderungan Cinderella Complex. Sebaliknya, semakin negatif konsep diri maka semakin tinggi tingkat kecenderungan Cinderella Complex.

Pendekatan belajar pada kecenderungan cinderella complex yang menyebabkan adanya ketakutan akan kemandirian pada perempuan dan rasa ingin ditalong oleh pihak luar dibentuk oleh proses belajar yang diterapkan dalam pola pengasuhan dan lingkungan sekitar yang selalu menempatkan anak perempuan pada posisi yang selalu ingin dilindungi. Hal ini sejalan dengan yang di kemukakan oleh Santrack (2002) bahwa "anak mengobservasi orang-orang 
dewasa dan teman-teman sebaya mereka dirumah, di sekolah, di tetangga, dan di televisi, dan terbuka secara luas terhadap banyak sekali model yang memperlihatkan perilaku maskulin dan feminim".

Faktor-faktar penyebab perilaku kecenderungan Cinderella Complex adalah suatu perilaku pola asuh yang diterapkan oleh orang tua yang dimana sangat memanjakan anak perempuannya tanpa memberikan kesempatan untuk belajar sendiri atau secara mandiri saat menghadapi / menyelesaikan masalah yang ada. Selain itu terdapat juga beberapa faktar kematangan diri yang mempengaruhi perilaku kecenderungan Cinderella Complex seperti kandisi fisik, kondisi lingkungan, faktor sosial budaya, maupun pengalaman masa lalu.

\section{b. Aspek-aspek Kecenderungan Cinderella Complex}

Dowling (Erwin, 2017:17) memberi gambaran bahwa perempuan yang mengalami cinderella camplex menunjukkan rendahnya kemandirian, yang kemudian ditunjukkan dengan aspek-aspek cinderella complex sebagai berikut:

a. Mengharapkan pengarahan dari orang lain

Ketergantungan pada perempuan telah mematikan inisiatif dan orisinalitasnya. Akibatnya perempuan selalu ragu-ragu dalam bertindak. Sesuatu hal dapat dikerjakan apabila sudah mendapatkan pengesahan secara susial. Tindakan atau keputusan akan diambil apabila sudah melalui tahap meminta pendapat atau pengarahan dari arang lain.

b. Kontrol diri eksternal

Aspek ini terlihat ketika perempuan mendapatkan keberhasilan dirinya berhenti pada titik tertentu dan tidak ingin meraih keberhasilan yang lebih jauh lagi. Hasil penelitian menunjukkan bahwa perempuan cenderung mengatribusikan atau melekatkan keberhasilan kepada sumber-sumber luar, misalnya saal keberuntungan. Selain itu cenderung merasa tidak mempunyai kontrol untuk memecahkan masalah sendiri atau untuk mempengaruhi lingkungan.

c. Rendahnya harga diri

Pada diri perempuan terdapat kurangnya harga diri, akibatnya seringkali menekan inisiatif dan membuang aspirasinya. Hal ini terkait juga dengan perasaan tidak aman yang sangat mendalam serta ketidakpastian mengenai kemampuan serta nilai diri mereka. Kurangnya harga diri berkaitan erat dengan kecemasan, perasaan lemah, dan tidak mampu. Dowling (dalam Sa'diyah,20IZ) menjelaskan perempuan yang tergantung memiliki harga diri (Self esteem) yang rendah sehingga sering sekali menekan inisiatif dan aspirasinya.

d. Menghindari tantangan dan kampetisi

Hal ini terkait dengan faktor emosional seperti takut salah, merasa tidak enak dengan teman, tidak bersemangat, kurangnya optimisme dalam hidup yang seringkali menghalangi kompetensi mereka untuk menghadapi ketakutan, persaingan, dan terus maju menghadapi segala rintangan.

e. Mengandalkan laki-laki

Ketergantungan dan kurangnya pengalaman membuat perempuan takluk dan mengandalkan laki-laki baik sebagai pelindungnya maupun secara ekonomis. Perempuan berani melakukan sesuatu jika ada laki-laki yang menyertai dan merestuinya. Tanggung jawab secara eknnamis dan pemimpin dibebankan pada laki-laki. Setiap kali perempuan menghadapi hidup yang semakin berat, kemungkinan menyerah dan masuk ke dalam perlindungan laki-laki selalu ada. Hal ini mengurangi kuatnya keinginan untuk bertahan mandiri. Perempuan cenderung berkembang menjadi pribadi yang tergantung pada laki-laki baik secara ekonomis maupun psikologis. Ketergantungan ini akibat dari perempuan memiliki kecemasan yang terlalu berlebihan dan nampak tidak memiliki alasan yang kuat. Sehingga hal tersebut menyebabkan orang tersebut tidak bisa melakukan hal apapun searang diri seperti telihat pasif dan tidak bisa melakukan hal apapun tanpa bantuan dari arang lain.

f. Ketakutan kehilangan feminitas 
Kaum perempuan diserang kepanikan gender yakni ketakutan bahwa kesuksesan dan kemandirian ketika bekerja adalah tidak feminine. Perempuan takut akan kehilangan karakteristik sebagai individu yang penuh kasih sayang, berbudi halus, hangat, kalem dan suka berhati-hati.

Berdasarkan uraian di atas dapat disimpulkan bahwa aspek-aspek cinderella complex terdiri dari aspek cenderung mengharapkan pengarahan dari orang lain, knntrol diri, rendahnya harga diri, menghindari tantangan \& kompetisi yang bisa mempersulit diri, mengandalkan orang lain atau laki-laki, serta ketakutan kehilangan feminimitas. Adapun batasan ketergantungan dari perilaku kecenderungan Cinderella Complex yaitu tidak menentu, ketergantungan itu muncul ketika ia merasa tidak berdaya saat menghadapi suatu masalah yang dapat mempersulit dirinya lalu tidak ada orang yang mampu menolongnya atau mendampinginya saat itu juga.

Mengacu pada penjelasan sebagaimana dipaparkan diatas, maka yang menjadi tujuan yang ingin dicapai dalam penelitian ini adalah sebagai berikut:

I. Tambaran perilaku kecenderungan Cinderella Complex pada kasus Mahasiswi di Fakultas Ilmu Pendidikan Universitas Negeri Makassar?

2. Faktar yang menyebabkan timbulnya perilaku kecenderungan Cinderella Complex pada kasus Mahasiswi di Fakultas Ilmu Pendidikan Universitas Negeri Makassar?

3. Keberhasilan teknik Restruturiksasi Kognitif dalam upaya penanganan masalah kecenderungan Cinderella Complex.

\section{METDDE}

\section{A. Pendekatan dan Jenis Penelitian}

Berdasarkan latar belakang masalah dan rumusan masalah yang telah ditentukan, pendekatan yang digunakan dalam penelitian ini yaitu pendekatan kualitatif. Sugiyono (20IG) mengatakan bahwa metode penelitian kualitatif sering disebut metade penelitian naturalistik karena penelitiannya dilakukan pada kondisi alamiah (natural setting); disebut sebagai metade kualitatif karena data yang telah dikumpulkan juga analisisnya bersifat kualitatif. Selain itu, hasil penelitian kualitatif lebih menekankan makna daripada generalisasi.

Jenis penelitian yang digunakan dalam penelitian ini yaitu studi kasus. Menurut Yin (Tohirin, 2012:20) studi kasus adalah salah satu metode penelitian bidang ilmu-ilmu sosial. Lebih lanjut, RabertK. Yin (Tohirin, 2012;2Z) mengatakan:

Studi kasus adalah suatu inkuri empiris yang menyelidiki fenomena di dalam konteks kehidupan nyata bilamana batas-batas antara fenomena dan konteks tak tampak dengan tegas, dan dimana multisumber bukti dimanfaatkan.

Berdasarkan penjelasan tersebut, maka peneliti menggunakan jenis penelitian studi kasus terhadap satu mahasiswi yang teridentifikasi mengalami kecenderungan Cinderel/a Camplex. Penelitian ini dilakukan secara mendalam untuk menemukan gambaran-gambaran serta faktor penyebab perilaku kecenderungan Cinderel/a Complex untuk kemudian dapat dilakukan perencanaan penanganan dengan melaksanakan atau memberikan layanan bimbingan konseling yang tepat untuk menangani perilaku kecenderungan Cindere/la Camplex.

\section{B. Kehadiran Peneliti}

Dalam penelitian ini, peneliti bertindak sebagai instumen kunci serta aktif dan pengumpul data dalam upaya mengumpulkan data-data di lapangan. Selain peneliti yang berperan sebagai instrumen kunci serta aktif juga insturmen manusia, dapat pula digunakan berbagai bentuk alat-alat bantu dan dokumen-dokumen untuk menunjang keabsahan hasil penelitian yang berfungsi sebagai insturmen pendukung. Dleh karena itu, kehadiran peneliti secara langsung dan aktif di 
lapangan dengan informan atau sumber data lainnya disini mutlak diperlukan, untuk menunjang atau sebagai tolak ukur keberhasilan penelitian.

\section{Subjek Penelitian}

Subjek dalam penelitian ini merupakan salah satu mahasiswi di Fakultas Ilmu Pendidikan UNM yang berinisial NDH. Dimana dalam hal ini, NDH ditetapkan sebagai kasus serta subjek penelitian karena berdasarkan studi pendahuluan NDH teridentifikasi mengalami kecenderungan Cindere/la camplex. Hal ini karena NDH menujukkan gejala cenderung meminta arahan kepada orang lain ketika ingin melakukan suatu pekerjaan, dan mencari perlindungan ketika menghadapi suatu masalah, selalu merasa apa yang dikerjakannya itu tidak sesuai, apabila mendapatkan hasil pekerjaan yang cukup / mendapatkan nilai yang sesuai standar kelulusan maka tidak ada usaha untuk mendapatkan yang lebih.

\section{Lokasi Penelitian}

Fakultas Imu Pendidikan Universitas Negeri Makassar terletak di لl. Tamalate I Rappocini, Karunrung, Kec. Rappocini, Kota Makassar, Prov. Sulawesi Selatan. Kampus ini memiliki tempat yang sangat strategis yaitu berada di tengah-tengah kota Makassar. Pemilihan lokasi penelitian ini karena berdasarkan studi pendahuluan yang dilakukan peneliti terdapat satu mahasiswi yang teridentifikasi mengalami kecenderungan Cinderella camplex.

\section{E. Jenis Data}

I. Data Primer

Peneliti menggunakan data primer ini untuk mendapatkan informasi langsung mengenai kecenderungan Cindere/la camplex, yaitu dengan wawancara terhadap satu mahasiswi. Sumber data utama diperoleh dari hasil abservasi yang kemudian dicatat melalui catatan tertulis. Peneliti menggunakan data berdasarkan kasus untuk mendapatkan informasi langsung tentang perilaku mahasiswi yang teridentifikasi yang mengalami kecenderungan Cinderella camplex di Fakultas IImu Pendidikan UNM.

2. Data Sekunder

Peneliti menggunakan data sekunder ini untuk memeroleh informasi dari arang tua, sahabat/teman dekat, serta teman special, yang diharapkan dapat memberikan informasi yang akurat untuk memperkuat dan melengkapi informasi yang telah dikumpulkan sebelumnya pada data primer.

\section{F. Teknik Pengumpulan Data}

Peneliti merupakan instrumen kunci serta aktif dalam penelitian kualitatif. Selain peneliti, teknik pengumpulan data juga diperlukan dalam penelitian kualitatif sebagai langkah utama dalam penelitian untuk mendapatkan data yang cukup valid. Adapun teknik pengumpulan data yang digunakan dalam penelitian ini, antara lain:

1. Observasi

Sitti Mania (2008) mengemukakan secara umum, observasi merupakan metade mengumpulkan keterangan atau data yang dilakukan melalui pengamatan dan pencatatan secara sistematis terhadap suatu fenomena kejadian atau perilaku yang sedang dijadikan sasaran pengamatan. Dengan kata lain, observasi dilakukan untuk memeroleh informasi tentang abservee yang sebenarnya. Senada dengan hal tersebut, Nasution (Sugiyono. 20I6: 3IC) menyatakan bahwa: observasi adalah dasar semua ilmu pengetahuan. Para ilmuan hanya dapat bekerja berdasarkan data, yaitu fakta mengenai dunia kenyataan yang diperoleh melalui abservasi

Dalam penelitian ini, observasi dilakukan untuk menganalisis perilaku kecenderungan Cinderella camplex pada mahasiswi berinisial NDH di Fakultas IImu Pendidikan UNM. Adapun aspek-aspek yang diabservasi Hal ini ditandai dengan tingginya ketergantungannya pada orang lain utamanya laki-laki, selalu ingin ditolong ketika mengalami suatu kesulitan oleh orang lain utamanya laki-laki, menghindari tantangan-tantangan ataupun kompetisi yang dapat mempersulit diri, 
merasa takut kehilangan feminimitas dalam melakukan suatu pekerjaan. Adapun ciri-cirinya adalah cuek, manja, suka melawan, pemalas, dan suka marah.

2. Wawancara

Selain melalui observasi, peneliti dapat mengumpulkan data melalui wawancara. Esterberg (Sugiyono. 20I6: 317) mendefinisikan wawancara sebagai berikut:

\section{Interview is a meeting of twa persuns to exchange information and idea through question and responses, resulting in communication and jaint construction of meaning abaut a particular topic.}

Wawancara adalah merupakan pertemuan dua orang untuk bertukar informasi dan ide melalui tanya jawab, sehingga dapat diknnstruksikan makna dalam suatu topik tertentu.

Untuk memudahkan wawancara dengan subjek, maka digunakan pedaman wawancara sebagai pegangan peneliti, agar wawancara dapat terstruktur dan terarah sesuai dengan tujuan penelitian. Melalui penelitian ini, peneliti menjalin hubungan dengan mahasiswi yang mengalami kasus dan subjek lainnya secara terbuka, akrab, intensif dan empati sehingga dapat diperoleh infarmasi yang akurat dan tidak dibuat-buat. Dengan wawancara mahasiswi yang mengalami kasus, juga dapat memahami perasaan dan berbagai fenamena yang dihadapi sehingga mengalami kecenderungan Cinderella camplex secara berulang dan terus menerus.

Teknik penelitian dengan metode wawancara dalam bentuk tanya jawab dengan mahasiswi yang teridentifikasi mengalami kecenderungan Cindere/la complex. Selain wawancara dengan si kasus, dengan orang tua si kasus, dengan sahabat/teman dekat si kasus dan juga wawancara dengan teman specia/si kasus. Dengan menggunakan pedaman wawancara. Hal ini dimaksudkan untuk mendapatkan informasi tentang peserta didik yang teridentifikasi mengalami kecenderungan Cindere/la camplex.

3. Dokumentasi

Menurut Kamus Besar Bahasa Indanesia (Sudarsano, B. 2017) mengartikan dakumentasi adalah pengumpulan, pemilihan, pengolahan serta penyimpanan infarmasi dalam bidang pengetahuan; Selain itu dokumentasi juga diartikan pemberian atau pengumpulan bukti dan keterangan seperti gambar, kutipan, video dan bahan referensi lainnya. Beberapa dokumentasi tambahan yang akan digunakan dalam penelitian ini adalah catatan-catatan dari yang dibuat oleh kasus.

\section{G. Teknik Analisis Data}

Menurut Spradley (Sugiyono. 2016: 334) menyatakan bahwa:

Analysis of any kind inva/ve a way of thinking. It refers to the systematic examination of something to determine its parts, the relation among parts, and the relationship to the whole. Analysis is a search for patterns.

Analisis dalam jenis penelitian apapun, adalah merupakan cara berpikir. Hal itu berkaitan dengan pengujan secara sistematis terhadap sesuatu untuk menentukan bagian, hubungan antar bagian, dan hubungannya dengan keseluruhan. Analisis adalah untuk mencari pola.

Analisis data yang dilakukan dalam penelitian ini di lapangan berdasarkan model Miles and Huberman. Miles and Huberman (Sugiyono. 2016) mengemukakan bahwa aktivitas dalam analisis data kualitatif dilakukan secara interaktif dan berlangsung terus menerus hingga tuntas, sehingga datanya sudah jenuh. Aktivitas dalam analisis data sebagai berikut: l. Data Reduction (Reduksi Data)

Data yang telah ditemukan di lapangan perlu dicatat secara teliti dan rinci, untuk itu perlu dilakukan reduksi data. Mereduksi data berarti merangkum, memilih hal-hal pokok, memfokuskan pada hal-hal penting, mencari tema dan polanya serta membuang yang tidak perlu. Pada penelitian ini reduksi data akan dilakukan setelah data perilaku kecenderungan Cindere/la camplexpada mahasiswi dan penanganannya di Fakultas Ilmu Pendidikan UNM diperoleh. 


\section{Data Display (Penyajian Data)}

Setelah mereduksi data, maka langkah selanjutnya adalah penyajian data atau mendisplaykan data. Penyajian data yang sering digunakan untuk penelitian kualitatif adalah dengan teks yang bersifat naratif. Tujuan display data adalah memudahkan untuk memahami apa yang terjadi, merencanakan kerja selanjutnya berdasarkan apa yang telah dipahami.

3. Conc/usion Drawing/Verification (Kesimpulan)

Langkah terakhir dalam analisis data kualitatif yaitu penarikan kesimpulan dan verifikasi. Kesimpulan awal yang dikemukakan masih bersifat sementara dan bisa berubah bila tidak ditemukan bukti-bukti yang kuat yang mendukung pada tahap pengumpulan data berikutnya. Namun apabila kesimpulan yang dikemukakan pada tahap awal, didukung dleh buktibukti yang valid dan konsisten saat peneliti kembali ke lapangan mengumpulkan data, maka kesimpulan yang dikemukakan merupakan kesimpulan yang kredibel (dapat dipercaya).

\section{H. Pemeriksaan Keabsahan Data}

Dalam penelitian ini, standar pengecekan dan keabsahan data dilakukan dengan uji kredibilitas data atau kepercayaan terhadap data hasil penelitian kualitatif antara lain dilakukan dengan triangulasi dan member check.

I. Triangulasi

Menurut William Wiersma (Sugiyano. 2016) triangulasi yaitu pengecekan data yang diperoleh dari berbagai sumber dengan berbagai cara dan berbagai waktu. Dalam penelitian ini triangulasi yang digunakan yaitu triangulasi sumber dan triangulasi metade/teknik.

a. Triangulasi sumber, bertujuan untuk menguji kredibilitas data dilakukan dengan mengecek data yang telah diperoleh dari beberapa sumber. Setelah melakukan wawancara kepada beberapa informan yang memiliki kedekatan dan mengetahui keadaan subjek yang diteliti seperti kepada orang tua, sahabat/teman dekat dan teman specia/, hasil wawancara dengan informan tersebut dideskripsikan dan dikategorikan dengan hasil wawancara dengan subjek untuk melihat mana data yang memiki pandangan sama dan pandangan yang berbeda. Jika data dari informan penelitian ini sesuai dengan data yang diperoleh dari subjek maka data tersebut memiliki tingkat kepercayaan yang tinggi sehingga tingkat kebenaran kesimpulan akhir hasil penelitian dapat dipertanggung jawabkan.

b. Triangulasi metode atau triangulasi teknik, dengan membandingkan hasil penelitian yang diperoleh melalui wawancara dengan data yang diperoleh melalui observasi. Setelah peneliti memeroleh data dari subjek penelitian melalui wawancara, maka peneliti melakukan observasi pada setiap pertemuan antara peneliti dan subjek. Pengamatan diupayakan tidak diketahui dan disadari oleh subjek agar tingkah laku yang ditampilkan sesuai dengan fakta yang sebenarnya dan apabila terdapat ketidaksesuaian antara hasil observasi dan hasil wawancara, maka peneliti akan melakukan diskusi lebih lanjut dengan subjek untuk memastikan data mana yang dianggap benar.

\section{Member Check}

Menurut Sugiyano (2016) mengemukakan member checkadalah proses pengecekan data yang diperoleh peneliti dari subjek. Apabila data yang ditemukan disepakati oleh subyek berarti data tersebut valid, sehingga semakin kredibel (dapat dipercaya) tetapi apabila data yang ditemukan peneliti dengan berbagai penafsirannya tidak disepakati oleh subjek, maka penelitipun melalukan diskusi dengan subjek dan apabila perbedaannya tajam, maka peneliti harus mengubah temuannya dan harus menyesuaikan dengan apa yang diberikan oleh subjek. Dengan kata lain, semua informasi yang diperoleh dan akan digunakan peneliti dalam penulisan laporan sesuai dengan yang dimaksud subjek.

\section{HASIL DAN PEMBAHASAN}


Sesuai dengan temuan penelitan secara berturut-turut akan dibahas mengenal gambaran perilaku kecenderungan Cinderel/a cumplex, faktor-faktor penyebab Cinderel/a complex, dan pelaksanaan teknik Cinderel/a camplexpada konseli NDH.

\section{Gambaran perilaku kecenderungan Cinderella complex pada konseli NDH}

Gambaran Cindere//a camplex terdapat enam aspek yang menjadi ciri perempuan mengalami kecenderungan Cinderel/a complex yaitu (I) Mengharapkan pengarahan darí orang lain, (2) kontral diri eksternal kurang, (3) rendahnya harga diri, (4) menghindari tantangan dan kompetisi. (5) mengandalkan laki-laki. (B) takut kehilangan feminitas dalam bekerja. Pada diri Konseli NDH terdapat empat ciri Cinderella complex yaitu (I) Mengharapkan pengarahan/pendapat orang lain seperti sering merasa ragu ketika dirinya akan mengambil suatu keputusan, dirinya baru akan memutuskan ketika sudah mendapatkan pengesahan secara sasial dari orang lain. (2) kontrol diri eksternal kurang seperti dirinya terkadang tidak ingin menggapai sesuatu yang lebih dari apa yang ia terima saat itu juga karena sudah merasa cukup atas yang diraihnya yang menurutnya sudah pantas sesuai dengan kemampuannya, (3) menghindari tantangan kompetisi seperti selalu tidak ingin mencoba hal baru yang bisa mempersulit / membuat dirinya tidak berdaya dan merasa tidak tahu harus melakukan apa saat itu, \& (4) mengadalkan / mengharapkan bantuan dari orang lain atau laki-laki seperti hampir setiap saat ketika tidak bisa melakukan segala sesuatu baik masalah berat maupun ringan sekalipun hal tersebut tidak dapat terselesaikan ketika dirinya tidak didampingi atau ditolong oleh laki-laki maupun orang lain. Pernyataan diatas didukung oleh ahli Dowling (Hapsari, 2014) memberi gambaran bahwa perempuan yang mengalami Cinderella complex menunjukkan rendahnya Kemandiran, yang kemudian ditunjukkan dengan aspek-aspek Linderel/a camplexsebagai berikut: (I) Mengharapkan pengarahan dari orang lain, (2) control diri eksternal kurang. (3) rendahnya harga diri, (4) menghindari tantangan dan Kompetisi, 5) mengandalkan laki-laki. (6) takut kehilangan feminitas dalam bekerja.

Berdasarkan pernyataan di atas peneliti dapat mengambil kesimpulan bahwa konseli NDH mengalami kecenderungan Cinderel/a complex yang cukup tinggi karena dari ke enam aspek yang menjadi ciri-ciri perilaku Cinderel/a Camplex terdapat 4 aspek yang sangat menonjol pada diri konseli NDH.

\section{Faktor penyebab kecenderungan Cinderella cumplex pada konseli NDH}

Faktor penyebab kecenderungan Cinderel/a complex dapat berasal dari Pola asuh, konsep diri, sasial budaya dan agama berdasarkan hasil penelitian menyatakan bahwa faktor penyebab kecenderungan Cindere/la cumplex pada konseli NDH yaitu dari faktor pola asuh yang diterapkan oleh kedua orang tuanya itu berbeda antara bapak dengan ibu. Dimana sang bapak sangat protektif terhadap NDH karena merupakan satu-satunya anak perempuan dari 3 orang bersaudara, sedangkan sang ibu sangat memanjakan dirinya dengan penuh kasih sayang serta perhatian yang banyak namun tidak membedakan perlakuan tersebut kepada anak-anaknya dan knnsep diri yang dimana terbagi lagi dalam beberapa poin.

Pernyataan diatas didukung oleh pendapat Handayani dan Novianto (2004), menunjukkan bahwa keyakinan yang tumbuh dalam konsep diri perempuan mengenai ciri-ciri sifat yang distreotipkan untuk mengakibatkan perempuan tergantung dan tidak kompeten. Menurut Harlock (1977) keberhasilan seseorang untuk mandiri adalah remaja harus memiliki konsep diri yang stabil. Konsep diri akan mcmbantu remaja dalam memandang dirinya dengan cara yang lebih konsisten sehingga akan meningkatkan harga diri dan memperkecil perasaan tidak mampu.

Menurut Anggraeni dan astuti (2003) pola asuh berpengaruh pada terjadinya kecenderungan Cinderel/a complex pada perempuan karena keluar merupakan kelompok sasial pertama dimana anak dapat berinteraksi. Pengaruh keluarga dalam pembentukan dan perkembangan kepribeadian sangatlah besar antinya. 
Berdasarkan pernyataan diatas peneliti menyimpulkan bahwa faktor penyebab kecenderungan Cinderella complex pada konseli NDH yaitu pola asuh yang diberikan oleh orang tuanya utamanya sang ibu yang selalu memanjakan sang anak sehingga sang anak merasa ibunya merupakan tameng untuk berlindung dari setiap masalah yang konseli NDH hadapi serta tidak diberikannya kesempatan untuk belajar menyelesaikan segala masalahnya secara mandiri dan juga konsep diri konseli NDH yang dikuatkan dengan beberapa pendapat ahli.

\section{Upaya dalam menangani kecenderungan perilaku Linderella complex pada mahasiswi di Fakultas llmu Pendidikan Universitas Negeri Makassar.}

Berdasarkan hasil pengamatan dan wawancara yang dilakukan oleh peneliti faktor yang menjadi penyebab terjadinya kecenderungan Cinderel/a complex pada NDH adalah pola asuh dan konsep diri yang dimiliki oleh NDH. Oleh karna itu peneliti memberikan penanganan dengan menggunakan teknik restrukturisasi kngnitif, yaitu dengan mengubah pikiran-pikiran atau keyakinan yang negatif menjadi lebih positif.

Proses pemberian bantuan dilakukan melalui 6 langkah yaitu (I) memberikan tujuan dan tinjauan singkat prosedur yang digunakan untuk memperkuat keyakinan knnseli bahwa permyataan diri negatif dapat mempengaruhi perilaku, (2) mengidentifikasi pikiran konseli ke dalam situasi masalah yang dilakukan untuk menganalisa pikiran konseli ke dalam situasi yang mengandung tekanan yang mampu menimbulkan munculnya kecenderungan Cinderella complex. (3) pengenalan dan pelathan coping thought yang bertujuan untuk memberikan kemampuan perpindahan fakus dari pikiran yang merusak/menyalahkan diri menuju pikiran yang lebih knnstruktif, (4) peralihan pikiran negatit ke coping thougt yang bertujuan untuk memberikan latihan menghentikan pikiran negatif kemudian mengarahkan pada pikiran netral pasitif dan tegas pada diri sendiri, (5) pengenalan dan lathan penguatan positif yang dilakukan dengan cara konselor yang memodelkan dan konseli mempraktikkan permyataan-pernyataan diri yang positif, (G) evaluasi diri yaitu meminta konseli untuk menjelaskan hasil lathan yang telah di alamı, mantaat yang dirasakan, dan mengetahui perubahan yang terjadi pada konseli.

Berdasarkan hasil evaluasi yang dilakukan menunjukkan hasil bahwa kecenderungan Cinderella complex pada NDH berkurang. hal ini ditunjukkan dengan tanggapan atau respon yang positif yang di kemukakan oleh Konseli NDH pada tahap evaluasi yang diberikan oleh peneliti. Hal ini juga dikuatkan dengan hasil wawancara ulang yang dilakukan oleh peneliti terhadap orang terdekat konseli yaitu pacar konseli NDH. Adapun perubahan pada konseli NDH yaitu (I) konseli NDH mulai mencoba untuk tidak meminta pengarahan kepada orang lain, (2) konseli NDH mulai untuk menerima tantangan dan kompetisi, (3) konseli NDH mulai mencoba untuk tidak meminta bantuan kepada laki-laki atau pacarnya, (4) konseli $\mathrm{NDH}$ berusaha lebih maksimal lagi untuk mencapai sesuatu atau nilai yang lebih baik dari sebelumnya.

\section{SIMPULAN DAN SARAN}

Hasil penelitian tentang kecenderungan perilaku Cinderel/a Complex dan penanganannya adalah sebagai berikut:

I. Gambaran perilaku Cinderella Camplex yang dilakukan oleh NDH adalah I) mengharapkan pengarahan dari arang lain, 2) control diri eksternal kurang, 3) menghindari tantangan dan kompetisi, 4) meminta bantuan dari orang lain, 5) takut kehilangan feminitas.

2. Faktor yang memengaruhi kecenderungan perilaku Cinderella Camplex NDH yaitu ; I) pola asuh pemanjaan, yang menuruti segala keinginan dari NDH, 2) knnsep diri, yaitu bahwa diri konseli harus dimanja, dilindungi, disayangi, harus dipenuhi semua keinginannya, dan harus mendapatkan pertolongan. 
Indonesian Journal of School Counseling: Theory, Application and Development

Volume I Nomar I Tahun 2021. Pages 41-52

p-ISSN: 2775-1708 \& e-ISSN: 2775-555X

Homepage: https://ojs.unm.ac.id/ijosc

DDI: https://dai.org/I0.26858/ijosc.vili.19322

3. Penanganan kecenderungan perilaku Cinderella Camplex pada konseli dilakukan dengan menggunakan teknik restrukturisasi kngnitif terdiri atas 6 tahap yaitu rational treatment, identifikasi pikiran kedalam situasi, pengenalan dan latihan caping thaught, peralihan pikiran negative ke caping tought, latihan penguatan pasitif, dan evaluasi. Setelah intervensi diberikan, terjadi perubahan pikiran konseli dari irrasional ke rasional.

Berdasarkan kesimpulan hasil penelitian di atas, diajukan saran sebagai berikut:

I. Bagi Kanselor.

Konselor dapat mempergunakan teknik restrukturisasi kognitif sebagai teknik layanan untuk mengurangi kecenderungan perilaku Cindere/la Camplex. Teknik restrukturisasi kagnitif dapat dikembangkan menjadi penelitian tindakan konseling dengan menerapkannya pada permasalahan yang berbeda.

2. Bagi peneliti selanjutnya.

Teknik restrukturisasi kngnitif dapat dikembangkan lebih lanjut dengan mengaitkan variable terikat lainnya.

\section{DAFTAR RUJUKAN}

Auliasari, D. 2018, Kecenderungan Cindere/la Camplex Pada Remaja Putri Yang Mengalami Broken Home. PSIKDBDRNED, Vol. 6 (2, 2018 : 448-456)

Mustari, A. (2016). Perempuan Dalam Struktur Sasial Dan Kultur Hukum Bugis Makassar. Al-'Adl, G(I), 127-146.

Qudsiyah, Imamatul. HUBUNGAN ANTARA KDNSEP DIRI DENGAN KECENDERUNGAN CINDERELLA CDMPLEXPADA MAHASISWI KEPERAWATAN. Diss. Universitas Islam Sultan Agung, 2019. (diakses pada 8 Mei 2020)

Sugiyano. 2017. Metade Penelitian Pendidikan: Pendekatan Kuantitatif, Kualitatif, dan R \& D). Bandung: Alfabeta.

Zain, T. Syarif. 2016. Cinderella Camplex Dalam Perspektif Psikologi Perkembangan Sasial Emosi. Jurnal Indegenaus, Vol. I (2016; 92-98). 